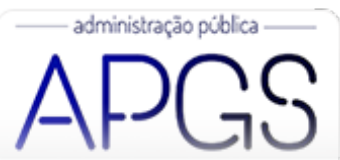

Administração Pública e Gestão Social ISSN: 2175-5787

apgs@ufv.br

Universidade Federal de Viçosa

Brasil

\title{
Immigration Administration in Brazil:Fragmentation and Lack of Coordination and its Challenges to Migration Policy
}

de Mendonça Fernandes, Janaina; Piffero Spohr, Alexandre

Immigration Administration in Brazil:Fragmentation and Lack of Coordination and its Challenges to Migration Policy

Administração Pública e Gestão Social, vol. 12, núm. 4, 2020

Universidade Federal de Viçosa, Brasil

Disponible en: http://www.redalyc.org/articulo.oa?id=351564289002

Esta obra está bajo una Licencia Creative Commons Atribución-NoComercial-SinDerivar 3.0 Internacional. 
Immigration Administration in Brazil:Fragmentation and Lack of Coordination and its Challenges to Migration Policy

Administración de inmigración en Brasil: fragmentación y falta de coordinación y sus desafíos para la política
migratoria
Administração da Imigração no Brasil: Fragmentação e Falta de Coordenação e seus Desafios à Política de Migração

Janaina de Mendonça Fernandes

Universidade Federal de Alfenas, Brasil

Redalyc: http://www.redalyc.org/articulo.oa?

janaina.fernandes@unifal-mg.edu.br

$\mathrm{id}=351564289002$

Alexandre Piffero Spohr

Universidade Federal do Rio Grande do Sul, Brasil

alexandre.spohr@gmail.com

Recepción: 14 Marzo 2018

Aprobación: 17 Julio 2019

Publicación: 01 Octubre 2020

\section{Resumen:}

Este artículo aborda la administración de la inmigración en Brasil. Su objetivo es arrojar luz sobre los procesos que implican el ingreso de extranjeros a Brasil. Se centra en los trabajadores y los refugiados y en las particularidades que marcan los procedimientos burocráticos para su admisión y regularización en Brasil. Al hacerlo, nuestro objetivo es aumentar la transparencia del proceso, ayudando a otros investigadores a avanzar en la agenda, pero principalmente a los usuarios del sistema para que se reconozca su estado más fácilmente. Las dificultades presentadas por la administración de inmigración brasileña se introducen a lo largo del artículo. Con base en la evaluación comparativa anterior de las políticas y bases de datos de migración de otros países, sugerimos algunas mejoras para Brasil. Estas sugerencias son especialmente relevantes en el contexto reciente. La aprobación de una nueva Ley de Migración en Brasil nos brinda la oportunidad de mejorar la política y la administración de la migración durante la regulación de este instrumento legal.

Palabras ClaVE: Transparencia, gestión pública, inmigración, gobernanza pública, asignación de procesos.

\section{ABstract:}

This article tackles the administration of immigration in Brazil. It aims to shed light on the processes that involve the entry of foreigners to Brazil. It focuses on both workers and refugees and on the particularities that mark the bureaucratic procedures for their admission and regularization in Brazil. By doing so, we aim to increase the transparency of the process, helping other researchers to advance in the agenda, but mostly the users of the system to have their status recognized more easily. The difficulties presented by Brazilian immigration administration are introduced throughout the article. Based on previous benchmarking on other countries' migration policies and databases, we suggest some improvements for Brazil. These suggestions are especially relevant in the recent context. The approval of a new Migration Law in Brazil presents us with an opportunity to improve migration policy and administration during the regulation of this legal instrument.

KEYWORDS: Transparency, public management, immigration, public governance, process mapping.

\section{Resumo:}

Este artigo aborda a administração da imigração no Brasil. Seu objetivo é lançar luz sobre os procesos que envolvem o ingresso de estrangeiros no país, especialmente trabalhadores e refugiado, bem como nas particularidades dos procedimentos burocráticos que enfrentam quando chegam ao Brasil. Nosso objetivo é aumentar a transparência do processo, auxiliando para que outros pesquisadores avancem nessa agenda, mas principalmente para ajudar usuários do sistema em seu estabelecimento no novo país. As dificuldades apresentadas pela administração da imigração brasileira são apresentadas ao longo do artigo. Com base na avaliação comparativa de políticas e bases de dados da imigração de outros países, sugerimos algunas melhorias que podem ser implementadas no Brasil. Essas sugestões são especialmente relevantes no contexto recente. A aprovação de uma nova Lei de Migração no Brasil oferece a oportunidade de melhorar a política e a administração da imigração durante a regulação desse instrumento legal. 
PalaVraS-CHAVE: Transparência, gestão pública, imigração, governança pública, mapeamento.

\section{INTRODUCTION}

This article is an effort to contribute to the reflection on immigration administration and on immigration policy in Brazil. Its goal is to shed light on the processes that involve the immigration of foreigners to Brazil, for various purposes, and to contribute to elucidating the dynamics that take place and the actors which are involved in this process. By doing so, we hope to increase the transparency of Brazilian immigration administration, to inform both political actors and the subjects of the process, and to encourage the debate on the matter.

By mapping the process of immigration in Brazil, we aim to verify which bodies are responsible for managing the entry of migrants in Brazil and for formulating Brazil's immigration policy. In order to gain depth into the subject, we shall dedicate special attention to data gathering points in this process, as it contributes to understanding the connection and communication between actors in the process. Previous efforts to reflect on this scenario, such as the exploratory work by Tadeu Oliveira (2016) in the Brazilian International Migration Observatory's 2016 Annual Report, introduce the need for integration of databases and processes for greater insight on the immigration phenomenon in Brazil. Oliveira highlights the potential of complementarity of existing databases, including those not exclusively devoted to migration, such as the census and the National Household Sample Survey (PNAD, acronym in Portuguese). The collection of data on immigration is also an issue of concern by international organizations, which has already been discussed by the Global Migration Group (Singleton, 2016).

Brazil is under unique circumstances for improving its immigration administration. On the one hand, there is great international reflection and discussion on the matter, as the refugee crisis is not yet over and important recipient countries, such as the United States and the United Kingdom harden the entry to their territories. On the other hand, Brazil has recently approved a new Migration Law and is under accession process to the Organization for Economic Cooperation and Development, what requires great improvements to administrative processes. Thus, we can perceive the current moment as a window of opportunity for the reflection on immigration management, allowing for comparisons to other countries and for finding out our fragilities in order to improve them.

The article is organized as follows. First of all, we briefly present the concepts and ideas behind our article. Second, we move toward introducing the methodology of process mapping used in this work. Then, we proceed to mapping the processes of immigration to Brazil, presenting the particularities that work-led immigration and refuge-seeking have. In order to deepen the debate on the matter, section 5 focuses on the collection of data on immigration that permeates all processes described and explained in the previous section. We believe this effort will provide greater insight on the challenges immigration administration currently presents. Finally, we draw some final remarks and some suggestions on how this could be advanced to allow for greater efficacy and transparency for public actions and greater insight and reflection.

\section{Mapping Processes}

Every important work conducted in an organization is a part of some process. There is no product or service supplied by a company that does not have a work process that generates it (Cury, 2005). However, processes must be aligned to the organization's strategic planning for it to reach the organizational excellence and the desired vision of the future. So, process modelling must not only enhance daily tasks, but also point toward the accomplishment of the entire organizational strategy (Ferreira, 2013). In this article, we use the concept of process as defined by Cury (2005, p. 303, our translation): 
We can define process as a series of tasks or steps that receive inputs (materials, information, people, machines, methods) and generate value-added products (physical products, information, service) used for the specific purposes of its receiver. Therefore, any type of work that is carried out in a company, in principle, must integrate a process.

NBR ISO 9000:2005 defines a process as "a set of interrelated or interactive activities that transform inputs into inputs (outputs)” (Associação Brasileira de Normas Técnicas [ABNT], 2005). Thus, processes can be seen under different approaches. They can be a group of activities carried out in a logical sequence with the objective of producing a good or a service that has value for a specific group of clients. Another view is to define them as any action or group of actions that adds value to an input to later provide an output to a client. Therefore, we can affirm that:

There is no product or service offered by a company without a business process. Likewise, it does not make sense to have a business process that does not offer a product or a service. In its most frequent conception, process is any activity or set of activities that takes an input, adds value to it, and provides output for a specific customer (Gonçalves, 2000, p. 7, our translation).

Finally, we can say that they are the specific ordering of work activities in time and space, with a beginning, an end, inputs and outputs, clearly identified. In short, we can state that they are a structure for action. Each of these definitions is valid and can be schematized in a simplified way. In this article, we follow the definition of process as a set of activities that use the resources of the organization to transform inputs into outputs, through the identification of needs and management, in order to perform certain tasks effectively.

Every organization has a set of processes and its elements can have different conceptions and generate different results. There are no organizations or products or services without processes. Even though these processes are not always documented, they are known and carried out by organizations in order to provide services and produce products for their customers.

Processes are part of the routine activities of a given organization and are carried out in a logical sequence with the purpose of producing a good or service that has added value for a group of clients, whether internal or external. Internal customers are those that are in the internal environment of the organization, translating the internal transformations of raw materials and other inputs and internal services, including administrative, until the conclusion of the product or service offered to the market. External customers are the consumers or users of the products and services offered by the organization.

It is important to point out that process is different from design, since the concepts have different nature. The project has beginning, middle and end in a certain time. It is punctual. It generates a specific result and it is produced to break and change the status quo. The process is permanent. It is standardized in time frames It produces goods and services; its purpose routinely. Thus, all important work done in organizations is part of some process (Curry, 2005).

The identification of processes by the organization in some cases does not gain much relevance, but it is an important step for organizational development. In order to identify the processes, there is need for special attention and strictness in order for no mistakes to be made, and for the actual processes within an organization to be identified.

The first thing we should do when starting a process mapping is to adopt a methodology. Such a methodology must follow an order of precedence that organizes the work of the person who maps processes. It must contain an initial analysis, an analysis of the current process, and the modeling of a new process, which must in the end generate more value for its client, whether it is an internal or an external one.

Therefore, process management should be focused on generating value, oriented to the efficiency and effectiveness of internal activities focused on the results to be achieved by the organization. With this, organizations need to have well-modeled and implemented work processes, so that they can obtain their efficiency, acting in a strategic way. According to Ferreira (2014, p. 23, our translation): 
Value adding relates to the perspectives and, thus, involves different dimensions of an organization: its shareholders, its suppliers, its products, and its customers. In the business world, for example, costs are no longer the determinants of the value of a product. The customer pays not only for the product, but for a series of intrinsic values, and do not always objectively state them. The value for the customer comes into existence at the moment when attributes, or a scale of importance, are added to the evaluation of what is offered. The identification of these attributes is essential for organizations, because they weigh in the competitive power in the market. In this case, the success of the organization vis-à-vis its competitors is a factor that implies adding value to the shareholders, which fuels the expectation of having their shares and their profits valued.

If in the private sector, a good process mapping makes a difference to value adding and, consequently, to fulfilling the organizational mission, the public sector is no different. According to the same author (Ferreira, 2014, p. 23, our translation):

Although the notions of value creation and value adding are very strong and evident in the business sector, they are not exclusive to these organizations. We can also consider the creation of value in public organizations, although, in this case, the reference is not the production for a consumer market, nor is it to meet the shareholders' expectations. [...] it is possible to admit the creation of public value in the public sector, based on collective needs and demands in a society.

With the understanding that process mapping and its subsequent good management is a preponderant factor for organizational success, we need to know how to proceed as these processes are being mapped. Thus, as the processes are being mapped, they are organized into graphic artifacts, which can be defined as graphic forms of representing how the processes are performed. This is done in order to understand in a didactic way how the process works, and to identify opportunities for improvement.

In this work, for the analysis of the processes of immigration in Brazil, the graphical form that we have used is a context diagram. The context diagram is a graphical tool, based on the Integrated Definition (IDEF) methodology, that allows us to understand the functioning of an organization by visualizing the existing work and business processes and the information exchanged between them and with suppliers and customers.

It aims to demonstrate a photograph of the iterations (relationships) between the processes of the organization. In this drawing, the processes present connections with each other that represent what is exchanged between them. These connections are called inputs, outputs, controls and mechanisms, such as the ICOM ${ }^{[\mathrm{i}]}$ in the IDEF methodology.

The input is the data that will be transformed by the activity. The control represents what restricts, normalizes or beacons the process. The output is the result of input processing, and the mechanism is the representation of the resources that support (generation) product. ICOM includes only data, information and everything that can be described as a process.

It is used to demonstrate the interaction between processes and points out:

a. What are the main inputs (inputs, internal and external);

b. What are the main outputs (products, internal and external);

c. What are the controls that standardize or parameterize processes; and

d. What are the main resources (mechanisms) used.

Bearing the aforementioned concepts and considerations in mind, we shall proceed to shedding light to the methodology and sources of data used in this article

\section{Mapping the Processes involved in Brazil's Immigration Administration}

The management of immigration policy in Brazil has its strategic goals defined by the law. This law is currently being changed as a new legal framework ${ }^{[i i]}$ has been approved and implemented. The Migration Law, federal law n. 13.445/2017, was sanctioned on May 24, 2017, and came into force on November 21, 2017. It was responsible for important changes, regarding goals, processes, definitions and rules applying to foreigners entering Brazil. Together with the Law of Refuge, federal law n. 9.474/1997, and some other legal, more specific, instruments - such as resolutions by the National Council for Migration and the National 
Committee for Refuge - rule how immigration can occur in Brazil. These are the sources we have resorted to in order to present the processes in play during immigration to Brazil.

The Migration Law was set to render immigration to Brazil easier and simpler. As the former law, created during a military dictatorship period, was very restrictive in many aspects, there was great need for updating immigration legal processes to current international standards and trends. The new law is originally focused on adapting to human rights considerations and although some of its important breakthroughs were vetoed by president Temer, it is expected to be less restrictive in practice. It is, thus, essential for we to understand how the organizational processes work, as they will probably see some changes in the near future. Although not much has changed since the new law has come into force, there is still much to be elucidated regarding immigration administration and room for it to be improved and rendered more transparent.

In order to map the processes in play in this article, we have used the methodology of Business Process Management (BPM) (Wesker, 2012), which is aimed toward managing organizational processes, aided by technological tools. This method is the result of an adaptation of best practices of management to processes integrated to information systems. BPM allows for more visibility of activities conducted in each of its business processes making them more efficient and adaptable to information systems platforms. Thus, we can say that BPM supports business processes to apply softwares involving the integration of people, systems, documents, and workflows adding more value to the results delivered to the internal and external clients of an organization.

The methodology of process mapping emerged in Management Studies in the late 1980s and early 1990s. Its objective was to offer more value added to goods and services supplied to clients and users of a company. When dealing with public organizations, the concepts of citizen and civil servant replace that of client. This offers a better perspective on the goals pursued by public activities and helps guiding activities of process mapping to better match public expectations.

Process managing is a recurring topic in Management, usually related to the subject of quality. Processes can be defined as a set of activities that make use of the organization's resources to transform inputs into outputs by identifying needs and managing activities in order to perform tasks more efficiently - i.e. a process receives an input, adds value to it and supplies an output to a specific client. By understanding how this set of activities works, one can draw a map of flows, which consists of a chart of processes of bodies that interact to perform a task and fulfill a goal in an organization.

This article analyzes the actions and responsibilities of each body involved in the immigration to Brazil, dividing it into two types. First, there is the work-led immigration. Then, we have the process of refuge. These two types of immigration are analyzed through the matrix of responsibilities and the diagram of context. The matrix of responsibilities identifies each body's attribution, and the diagram of context illustrates how they interact, showing policy users' inputs, and the results of the interaction. The analysis of these Management tools allows us to map not only the processes in the immigration policy, but also how data on the Brazilian migration flows is collected.

To map the processes under Brazil's immigration administration, we have analyzed documents (laws, normative resolutions, executive decrees, and other regulations) and conducted qualitative analysis. This consisted of semi structured interviews and gatherings with decision-makers and public policy-makers. By identifying performance gaps, actions and responsibilities overlaps, and their consequences, it is possible to draw maps of flows (Figures 1, 2 and 3).

The Brazilian case, of an immigration policy executed and implemented by different federal government bodies, presents us with some important challenges to understand and to discuss the administration of immigration. This is an issue not only to migration analysts in the country, but also to policymakers and to the migrants themselves, who suffer the consequences of inefficient practices due to the lack of an organized and integrated information system. This issue raises difficulties to a strategic immigration policy and to its adequacy to international standards and best practices examples. 


\section{Brazilian Immigration Policy and Administration}

The three ministries responsible for immigration policy and administration in Brazil are the Ministry of Labor (MTE), the Ministry of Foreign Affairs (MRE) and the Ministry of Justice (MJ). Two other important bodies that deal with migration are the National Immigration Council (CNIg), responsible for formulating the policy by gathering representatives from other bodies, and the Federal Police (PF) - associated with the Ministry of Justice -, responsible for controlling and ensuring the safety of the national borders and for registering foreigners. Other bodies that play significant roles in the process of refuge are the United Nations High Commissioner for Refugees, the National Committee for Refuge (CONARE) and Caritas Brazil.

The Ministry of Labor deals with migration under the perspective of the Brazilian labor market, with special attention to the qualification of the immigrant. According to article 27 of federal law n. 10.683, approved on May 28, 2003, the MTE is responsible for, among other things, the immigration policy. The General Coordination of Immigration (CGIg) is an administrative unit of the MTE that decides on requests of work permits for foreigners. It is responsible for planning, coordinating, guiding and supervising activities related to work permit for foreigners and to the recruitment or transfer of Brazilians overseas, besides providing technical and administrative support for the National Immigration Council.

In terms of data collection, the MTE maintains two tools since 2009 to facilitate the process of requesting work permits in Brazil. First, the Electronic Database for Requiring Entities of Work Permits for Foreigners (CERTE) is an electronic system that allows companies and organizations in Brazil to request permits to hire foreign workers and to update information and documents required by the CGIg. Secondly, the MIGRANTEWEB is a system directed towards the immigrant who also aims to obtain a work permit, allowing him or her to request it directly to the CGIg. These tools aim to facilitate and accelerate the processes.

Besides, the Ministry of Labor is also responsible for administrative registries of every worker in the Brazilian formal labor market, which also includes migrants. Even if those databases are not designed for migration issues, they are largely used due to its comprehensive account of the labor market. The Annual Social Information Report (RAIS) database brings yearly detailed information on each worker, while the General Registry of Employed and Unemployed (CAGED) database has monthly information on the state of admissions and dismissals. The Ministry of Labor also keeps registry of the Work and Social Security Registry (CTPS), which is a document needed by natives and migrants to work. Some efforts in crossing information through those databases are being made by MTE and the Brazilian International Migration Observatory (OBMigra).

The National Immigration Council is a body linked to the MTE, gathering 20 representatives in a quadripartite configuration, besides 13 observer entities. The CNIg is responsible for formulating the goals for the immigration policy, coordinating and guiding immigration activities, promoting studies to deal with immigration, listing periodically the national foreign workforce needs, establishing rules for the selection of immigrants, defining questions and solving missing cases regarding immigrants, weighing in with changes to legislation on immigration, and elaborating its own Internal Regiment that needs MTE's approval.

The federal government holds nine seats in the CNIg, each for a different ministry: MTE, MJ, MRE, Ministry of Agriculture, Livestock and Supply, Ministry of Health, Ministry of Development, Industry and Foreign Trade, Ministry of Science, Technology and Innovation, Ministry of Education and Ministry of Tourism. Five labor unions hold a seat each: Brazilian Workers' Central, Unified Workers' Unit, Syndical Force, Workers' General Union, and Brazilian Workers' General Central. Five employers' associations have representatives: National Confederation of Industry, National Confederation of Commerce of Goods, Services and Tourism, Confederation of Agriculture and Livestock of Brazil, National Confederation of Transport, and National Confederation of Financial Institutions. Finally, the scientific and technological community is represented by the Brazilian Society for the Advancement of Science. 
The 13 observer entities are not entitled to vote. They are the following: National Commission for Population and Development, Institute for Migrations and Human Rights, International Labor Organization, International Organization for Migration, Special Secretariat of Policies for Women (MJ), Secretariat of Social Security Policies (part of the former Ministry of Social Security[iii]), Ministry of Human Rights, Secretariat of Racial Equality Promotion (MDH), Public Defender's Office, Federal Attorney General's Office, Federal Police, Brazilian Intelligence Agency, Public Prosecutor's Office, and Public Labor Prosecutor's Office (Lista de Membros do Conselho Nacional de Imigração, 2017).

Some of the ministries represented in the CNIg promote specific actions regarding immigrants, for which special databases are created. For example, the Ministry of Health, and its Advisory Council for International Health Affairs, creates guidelines, coordinates and implements the ministry's international health policy. The Ministry of Education conducts projects such as Border's School, which promotes bilingual schools and will be expanded to other MERCOSUR countries.

The Ministry of Foreign Affairs has as its institutional mission to help the president in formulating the Brazilian foreign policy and ensuring its execution, maintaining diplomatic relations with foreign governments and international organizations and promoting Brazil's interests abroad. According to article 27 of federal law n. 10.683, from May 28, 2003, the MRE is responsible for diplomatic relations and consular services. The latter include issues related to foreigners abroad who wish to come to Brazil for any reason, which are tackled by Brazilian representations abroad. The ministry decides on matters of tourist visas to foreigners, its main attribution, but also works as a link between the foreigner overseas and the Ministry of Justice for permanent visas and the Ministry of Labor for work visas.

The Ministry of Justice, whose mission is to guarantee and promote citizenship, justice and public security, is responsible for permanent visa approval and grant of residence, besides the recognition of refugees and asylum seekers. It is mainly compromised to a human rights agenda through its Department of Foreigners and its Department of Migrations.

Besides, the Federal Police, which is an autonomous branch of the MJ, is responsible for registering all immigrants in Brazil through the National Record of Foreigners. Its approach to immigration policy is concerned with national and public security. It tackles the processing, judging and decision-making regarding nationality, naturalization and the legal regime of foreigners, such as expulsion, extradition and deportation.

The Federal Police deals with border control, but also operates as a link between foreigners in Brazil and the $\mathrm{MJ}$ for residence granting, requests for and transformation of student visas into work visas, and naturalization requests. It is only with an explicit authorization that a foreigner can direct its request directly to the MJ. Work permits for foreigners that are in Brazilian territory must be requested directly to the MTE.

The Federal Police maintains different autonomous digital systems, which contributes to the fragmentation of information about foreigners in Brazil. Among these are the System of Registration and Record of Foreigners (Sincre), the System of International Traffic (Sinte), and the System of Information on Processes (Siapro), in addition to an older version of the System of International Traffic (STI). The MJ, besides using the Siapro for the processes under its supervision, holds the data on naturalization requests and has access to all systems controlled by the Federal Police.

The analysis of the bodies that work together to manage and control the migration of foreigners to Brazil allows us to notice that there is a small predominance of the Ministry of Labor in the process, as the CNIg is directly linked to it. This should represent an overall focus on the benefits of the immigration of workers to the development of our country. However, as noticed by different researchers on the subject (Coentro, 2011; Reis, 2011), the Brazilian migration policy still lacks an approach focused on benefiting from the immigration of workers.

With the overall attributions of the three ministries that take part in the administration of the entry of foreigners into Brazil, we may now proceed to the processes in play during immigration. To do so, we will focus on the two main reasons for migration: work and refuge. Each will be described in a specific section. 


\subsection{The Administration of Work-Led Immigration}

The search for work or subsistence elsewhere is one of the most ancient reasons for leaving one's home for some other place. As the borders became more controlled, there is a great need for understanding how the entry of workers into the Brazilian market is managed by local authorities. By mapping the processes of each of the bodies described above, it was possible to draw Figure 1, which shows how they interact and how their inputs and outputs in the work-led immigration to Brazil are produced and converted. Figure 1, therefore, exhibits the processes that take place for a migrant to enter Brazil or for a foreigner to regularize his/her situation in Brazil.

First of all, we must distinguish the situation of foreigners inside and outside Brazilian borders. For any foreigner to enter Brazilian territory, there is the need for previous approval by Brazilian authorities. According to treaties between Brazil and other countries and to unilateral decisions by the Brazilian government, there are exemptions of visa for citizens of specific countries when they wish to enter Brazil for short periods of time - usually no more than 90 days - for tourism or work-related reasons. However, any foreigner wishing to move to Brazil will previously need an authorization, which is issued by the representations of the Ministry of Foreign Affairs abroad.

A foreigner overseas pursuing the required authorization to reside in Brazil shall contact the nearest Brazilian consulate or embassy in order to apply for a visa. In order to apply for a visa that allows for a larger period of time in Brazil, he or she must have already found employment, and his or her employer in Brazil shall contact the Ministry of Labor. The MTE will issue a work permit, which will be sent to MRE for the issuance of a visa.

When in Brazil, a migrant must focus on regularizing his/her situation with the national authorities. First, he/she must register with the Federal Police, which controls the permanence of every foreigner in national territory. Also, the migrant needs to request for a status of permanence from the Ministry of Justice, as no visa issued abroad will allow for this status. The permanence of foreigners in Brazil is directly tied to he/ she being allowed to work and to find employment. Although there are exceptions to this model, this is the normal flow of work-led immigration in Brazil.

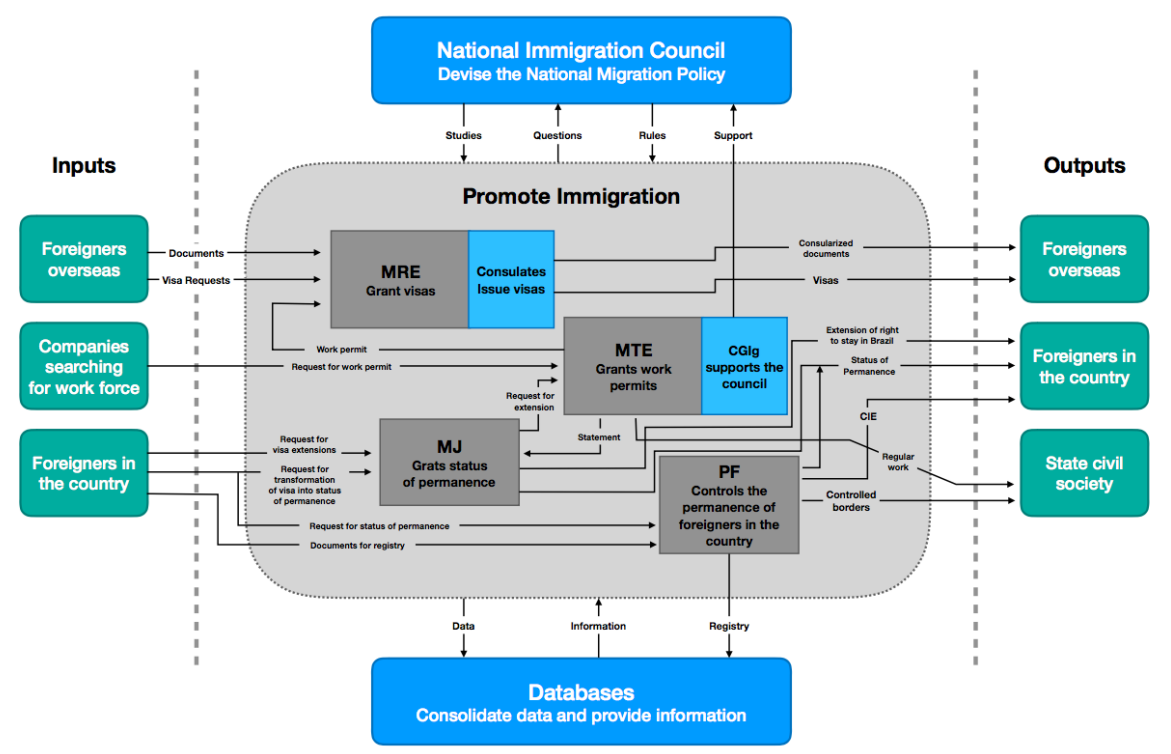

Figure 1 - Map of Flows of the Work-Led Immigration to Brazil Source: Fundação Getulio Vargas/Department of Public Policy Analysis (2015). 
The map of flows allows us to understand how the immigration to Brazil works in terms of processes and involved bodies. It also contributes to the identification of the points of data collection on immigration in Brazil and the bodies responsible for these tasks, with special focus on workers' migration.

The analysis of the map of flows leads to the conclusion that there is a great need for the integration of actions and systems involved in the Brazilian migration policy. Each involved party is responsible for an integral part of the process, with close ties to the others' activities. This would be made easier, faster and, most important, more accurate and safer if the systems and processes were to be integrated. Besides, the full understanding of the process needs precise information on what the integration of systems would allow to be collected, with comprehensive and accurate statistics about the subject.

\subsection{The Administration of Refuge}

An equally ancient reason for leaving his/her home country is the perception of danger in its permanence there. Recent humanitarian crisis in the Middle East, Africa and Latin America have raised the number of refugees worldwide. According to the Ministry of Justice (Refúgio em Números, 2016), 9.552 people have had their refugee status recognized in Brazil. They hold 82 different nationalities, and the Syrians are among the largest groups of refugees, accounting for 3.772 refugees in Brazil.

The definition of refugee in the 1951 Refugee Convention and in the Law of Refuge, however, is very restrictive and does not account for two important flows of migrants - Haitians and Venezuelans - fleeing from deteriorating conditions in their home countries. Since the earthquake that struck the Western part of the Hispaniola Island, Brazil has been receiving large flows of Haitians. The year of 2017 has witnessed a great increase in the number of nationals from Venezuela entering the country as the economic and food crisis in their country reached a worrisome situation. Although usually requesting refuge to Brazilian authorities, nationals from these two countries are not allowed to be granted this status and receive different treatment, according to CONARE's decisions.

The process of receiving refugee status in Brazil involves mainly the Ministry of Justice and the Federal Police. Figures 2 and 3 show the two main flows of processes that lead a foreigner seeking refuge to him or her receiving refugee status in Brazil. According to federal law n. 9474/1997, a foreigner entering Brazil may request refuge to any migration or border control authority. This request leads him/her to the simplest bureaucratic path to refuge. An alternative is to contact Caritas Brazil, which helps foreigners in their request for refuge, creating a second path, which involves more authorities.

Figure 2 shows the simplest path for a foreigner to receive refugee status. First, he/she will contact the Federal Police or the border migration authority and formally request refuge. The foreigner will fill a form produced by CONARE stating the grounds for leaving the origin country and the reason to ask for refuge. This form, called the Declaration Term, will be sent to the National Committee for Refuge. This body will issue a provisional identification document, with the number of refuge request, which needs to be renewed every 180 days while the request has not yet been evaluated. This document allows the foreigner to request a Natural Persons Register (CPF) and an employment record book. These documents allow him/her to seek employment in Brazil.

The request of refuge involves an interview of the applicant with the CONARE, in one of its local agencies or in one of the offices of the Public Defense. The interview will subsidize a report by a group of specialists, which will inform the decision of CONARE of granting or denying the foreigner refugee status. Besides the National Committee for Refuge, the UNHCR and Caritas, among other groups, take part in the group that issues the report on the requests. If the status is granted, the refugee may request his/her permanent documents. 


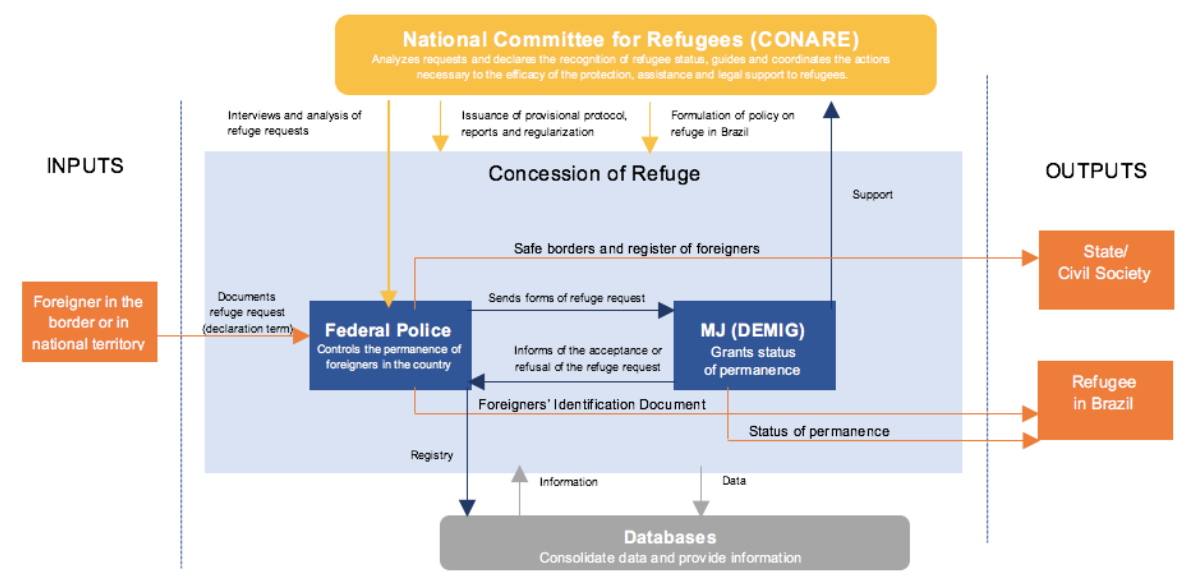

Figure 2 - Map of Flows of Refuge in Brazil - simplest path

Source: Fundação Getulio Vargas/Department of Public Policy Analysis (2017).

If a foreigner does not wish to contact the responsible authorities directly, he/she may seek the help of Caritas Brazil. This organization can act as an intermediary in the process, helping the foreigner seeking refuge to have his/her status recognized. Caritas Brazil has two host centers for receiving refugees, in Rio de Janeiro and in São Paulo, and some associated entities operate in other cities on behalf of Caritas. It has a team of lawyers and social assistants that help refugees with the information and legal assistance needed for them to be successful in their request. As shown in Figure 3, the process is very similar to the first. It mainly involves the assistance by Caritas to the refugee.

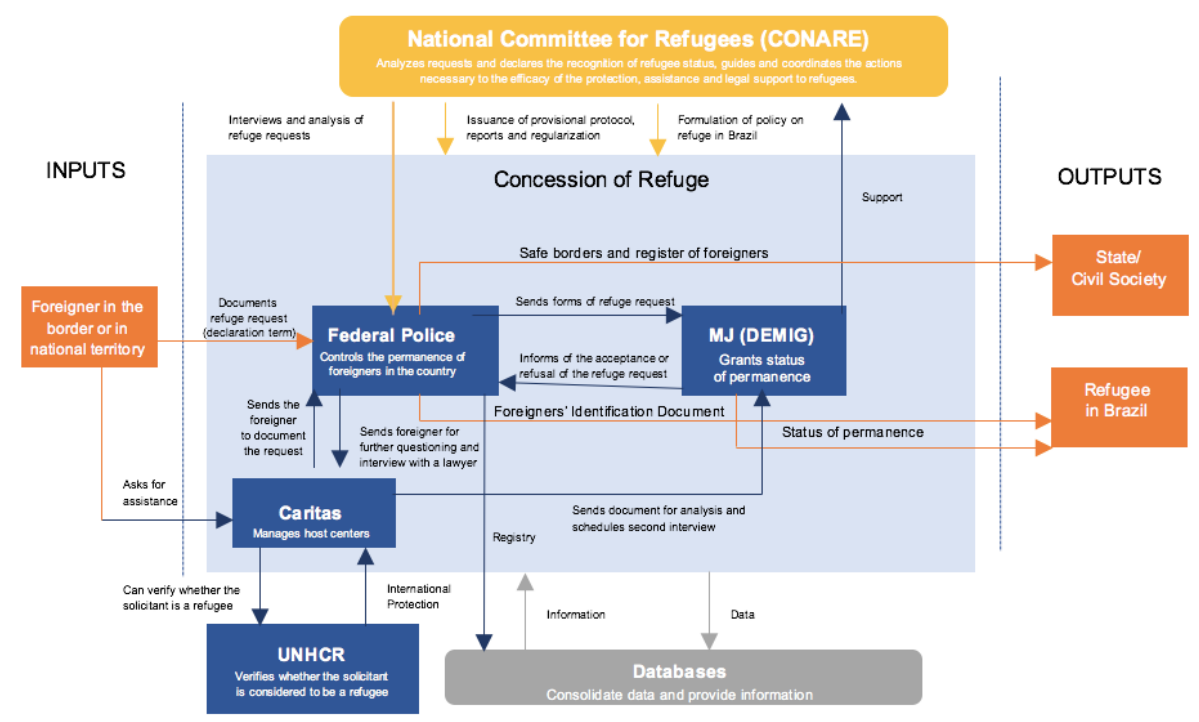

Figure 3 - Map of Flows of Refuge in Brazil - Caritas involvement Source: Fundação Getulio Vargas/Department of Public Policy Analysis (2017).

\section{Collecting data on immigration: a case to understand the problems of immigration administration in Brazil}

The situation of the migration administration in Brazil can be better assessed when we analyze how data on this phenomenon is collected by public authorities and how it is used. In this section, we present the main bodies responsible for collecting data and the main databases that are created and fed with information on 
the flows of foreigners entering Brazil. With this information in mind, we will be able to understand the main fragilities of the public administration of migration flows in Brazil.

As Table 1 shows, the monitoring of immigration to Brazil is fragmented, as this role is distributed among three ministries, together with subsidiary bodies. Adding to the low level of integration between the ministries' data, the systems are autonomous, without interaction with one another, even between those of the same ministry. Information on foreigners entering national territory is spread around databases and, therefore, incomplete. This makes it more difficult to control foreigners in the country and to draft a migration policy that really tackles Brazil's need for foreign labor. This situation helps explaining why MTE' responsibility of elaborating studies on immigrant's participation in the Brazilian development is neither consolidated, nor implemented. Both the efficiency and the transparency of migration administration are, therefore, jeopardized by this lack of coordination.

Table 1 - Databases on Immigration to Brazil

\begin{tabular}{|c|c|c|}
\hline Body & System & Goal \\
\hline \multirow[t]{4}{*}{$\begin{array}{l}\text { Ministry of } \\
\text { Justice and } \\
\text { Federal Police }\end{array}$} & $\begin{array}{l}\text { System of Registration and } \\
\text { Record of Foreigners } \\
\text { (Sincre) }\end{array}$ & Registers foreigners in the country \\
\hline & $\begin{array}{l}\text { System of International } \\
\text { Traffic (Sinte) }\end{array}$ & Registers international traffic \\
\hline & $\begin{array}{l}\text { System of Information on } \\
\text { Processes (Siapro) }\end{array}$ & $\begin{array}{l}\text { Allows to monitor the immigrant's } \\
\text { process }\end{array}$ \\
\hline & $\begin{array}{l}\text { System of International } \\
\text { Traffic (STI) }\end{array}$ & $\begin{array}{l}\text { Older version of System of } \\
\text { International Traffic }\end{array}$ \\
\hline \multirow[t]{5}{*}{ Ministry of Labor } & $\begin{array}{l}\text { Electronic Database for } \\
\text { Requiring Entities of Work } \\
\text { Permits for Foreigners } \\
\text { (CERTE) }\end{array}$ & $\begin{array}{l}\text { Receives demands of work permits by } \\
\text { companies and organizations and } \\
\text { allows them to keep information and } \\
\text { documents updated according to CGIg } \\
\text { requirements }\end{array}$ \\
\hline & MIGRANTEWEB & $\begin{array}{l}\text { Allows immigrants to request work } \\
\text { permit and later sends the request to } \\
\text { the CGIg }\end{array}$ \\
\hline & $\begin{array}{l}\text { Annual Social Information } \\
\text { Report (RAIS) }\end{array}$ & $\begin{array}{l}\text { Presents a comprehensive annual } \\
\text { administrative registry for every } \\
\text { worker in Brazil, including migrants }\end{array}$ \\
\hline & $\begin{array}{l}\text { General Registry of } \\
\text { Employed and } \\
\text { Unemployed (CAGED) }\end{array}$ & $\begin{array}{l}\text { Shows monthly registry for labor } \\
\text { market movements. It is possible to } \\
\text { retrieve migrants crossing it with CTPS } \\
\text { database. }\end{array}$ \\
\hline & $\begin{array}{l}\text { Work and Social Security } \\
\text { Registry (CTPS) }\end{array}$ & $\begin{array}{l}\text { Database on the work documents, } \\
\text { which is necessary for every worker, } \\
\text { including migrants }\end{array}$ \\
\hline $\begin{array}{l}\text { Ministry of } \\
\text { Foreign Affairs }\end{array}$ & $\begin{array}{l}\text { Integrated Consular } \\
\text { System }\end{array}$ & Grants visas to foreigners overseas \\
\hline
\end{tabular}

Source: Fundação Getulio Vargas/Department of Public Policy Analysis (2015).

In order to increase the understanding of the situation of the Brazilian migration administration, it is interesting to compare the collection of data here with other countries. For this purpose, OECD's International Migration Outlook presents us interesting ideas for comparison. The 2016 edition collected the most recent data on migration regarding its member countries (OECD, 2016). Under the title "Country notes: Recent changes in migration movements and policies", chapter 5 allows for a comparison among its 
members regarding migration flows, temporary migration, asylum seekers' flows, stock of immigrants, labor market outcomes, among other things. The table "Recent trends in migrants' flows and stocks", present in every country section of chapter 5 , helps bringing insight on the dimension of the migration phenomenon in each analyzed country.

Brazil, in its recent move towards joining the organization, shall be added to such data collection efforts in the future. By mapping processes of the immigration to Brazil and drawing the map of flows, we aim to contribute to the reflection on the accessibility of data by different publics. The overall difficulty to have access to information for comparison poses a challenge to the transparency of migration administration in Brazil and to its efficacy, as the databases lack communication and integration. This would provide more accurate information regarding the policy needs of the country regarding migration. A preliminary remark need to be made: the data informed in the table of OECD's study does not cover all countries and categories. This shows that the lack of transparency is an issue in those countries as well. The selection of OECD's study is motivated by the wide range of cases, what can be used for further studies in the future.

A first remark in the light of the analysis of the data in the study and searched for in Brazilian databases is that many categories of migration are not standardized in national and international databases, making it harder to compare them among other countries. Some of the data selected by the International Migration Outlook 2016 can be found in Table 2. 
Table 2 - Recent trends in migrants' flows and stocks in Brazil in 2014

\begin{tabular}{|c|}
\hline Migration flows by type \\
\hline Work \\
\hline Family \\
\hline Humanitarian \\
\hline Free movement \\
\hline Others \\
\hline Total \\
\hline Temporary migration \\
\hline International students \\
\hline Trainees \\
\hline Working holiday makers \\
\hline Seasonal workers \\
\hline Intra-company transfers \\
\hline Other temporary workers \\
\hline Inflows of asylum seekers \\
\hline Per 1000 inhabitants \\
\hline $\begin{array}{l}\text { Stocks of immigrants (Percentage of the } \\
\text { population) }\end{array}$ \\
\hline Foreign-born population \\
\hline Foreign population (2013) \\
\hline Labor market outcomes \\
\hline Employment/population (\%) \\
\hline Native-born men \\
\hline Foreign-born men \\
\hline Native-born women \\
\hline Foreign-born women \\
\hline Unemployment rate ( $\%$ of the labor force) \\
\hline Native-born men \\
\hline Foreign-born men \\
\hline Native-born women \\
\hline Foreign-born women \\
\hline
\end{tabular}

Source: OECD (2017).

Bearing Table 1 in mind, we will now proceed to explaining where information on those categories can be found in Brazilian databases. First, data on migration by type of flow appears in the System of Registration and Record of Foreigners. However, they are categorized under different labels, with a special focus on the normative resolutions or laws that grant legal validity to the entry of the foreigner into Brazil. Data on how many migrants with work related visas can be found in the Ministry of Labor database, fed through the work of the National Immigration Council and the General Coordination of Immigration. 
However, subsequent categories present greater difficulties to have their data collected. To verify how many immigrants were motivated by family-related affairs, we have to check how many were legally supported by CNIg's normative resolution 108/2014, regulating family reunion, which might be a good approximation.

Humanitarian flows can be considered to be the migration of refugees, humanitarian visa-holders and asylum-seekers. Here, special attention must be granted to Haitians, who receive special treatment in Brazilian migration law according to normative resolution 97/2012, with some changes by normative resolution 102/2013 and normative instruction 113/2014 (Resolução Normativa n. 102, 2012).

While the category free movement cannot be adapted to labels attributed to migration flows in Brazilian databases, some of the categories of Brazilian systems have to be ignored, as OECD's classification does not include transborder, permanent, or provisional migrants. The total number of immigrants entering Brazil in 2014 can be found in Sincre. By subtracting the categories found from the total flow, we can gather what can be labeled "other" flows.

The classification of temporary migrants posed special difficulties for collecting data. The number of international students entering Brazil can be found in Sincre by looking for those classified under paragraph IV of article 13 of Federal Law n. 6815/1980. Meanwhile, Sincre presented the amount of working holiday makers by classifying them under the paragraph $\mathrm{V}$ of the same law.

As mentioned earlier, federal law n. 6815/1980, called the Foreigners' Statute dealt with the legal situation of foreigners in Brazil, and its fifth article establishes the kinds of visas that can be granted to foreigners. This law has been replaced in 2017 by the Migration Law, but no significant changes have been made regarding the kinds of visas. Other kinds of temporary migrants were not classified according to OECD's methodology.

To search for numbers on asylum-seekers in Brazil, we have to look for data from the United Nations High Commissioner for Refugees, the UN Refugee Agency. Meanwhile, the Brazilian International Migration Observatory presents an estimation on the percentage of foreign population in Brazil for 2013, but does establish a distinction in terms of foreign-born Brazilians.

Finally, although the National Household Sample Survey (PNAD) does present important insights on the situation of the labor market in Brazil, its does not provide us with the necessary information on employment and unemployment rates for foreigners. This might be caused by the small participation of foreigners in the Brazilian population, which would result in sampling problems. Due to the lack of information in the PNAD, we have to resort to using data from the Brazilian census, which dates back to 2010.

\section{Final Remarks}

The effort here made to map the bureaucratic and legal processes that involve the admission and regularization of foreigners in Brazil has confirmed the idea that there is still much to be done to increase the efficiency of the Brazilian immigration administration. The processes we have introduced here lack transparency and, most importantly, the actors and bodies involved in those processes lack communication and integration. The difficulties perceived while analyzing the processes led us to suggest some changes that might improve immigration administration in the future.

First of all, the processes that involve immigrants in Brazil are not as clear as we have attempted to show them. The context diagrams presented in this article were the result of intensive study and research on laws and rules and of interviews and talks to bureaucrats responsible for their implementation on daily bases. A foreigner trying to move to Brazil, for work or to flee from the dangers of his/her home country, usually faces the difficulty of not finding clear information on what has to be done to have his/her situation regularized. So, there is a great need to publicize the context diagram to all of those who wish to immigrate to Brazil. This would increase the success rates of the applications for permanent and refugee status, while reducing the applications of those not entitled to them. 
By mapping the processes involving migration, we have also witnessed the lack of integration between the bodies involved in the process. This presents important challenges to the efficacy and to the efficiency of immigration administration. The fragmentation of duties in the process, which is probably caused by the need for specialization of the actors in each part of the chain, should be accompanied by intense communication between bodies. If there was more dialogue between the parties, work and means could be spared and greater fluidity would be given to the process.

The lack of integration gains special importance when the databases on immigration are analyzed. Data about migration in Brazil is spread across different bodies and systems, lacking harmonization of the information required from users and civil servants (when inserting data in the systems) and communication between different bodies and systems. The absence of a unified system with information about the migration phenomenon is a great issue for the Brazilian immigration administration, as there is not enough data to inform policy makers when making decisions regarding immigrants. This situation also renders the condition of immigrant in Brazil more complex and less stable. Having to gather different information in various systems, the immigrant is vulnerable to changes in the systems and to longer waiting periods for having their situation regularized.

Important changes to the management of data on immigration in Brazil can be based on policy benchmarks from other countries. The creation of a unified database for statistics on immigration, like the ones in Australia, Canada and Germany (Department of Immigration and Border Control - Statistics, 2017; IRCC - Statistics and Open Data, 2017; DESTATIS - Migration \& integration, 2017), is an interesting example to be followed. Even though Brazil does not have a specific body for migration policy, improvements might come from developing an information platform to inform possible migrants and give more transparency to the process, integrating the different bodies through data. The expansion of the open data policy to include migration issues, following efforts by the federal government to improve the openness of information on public policy, according to the Access to Information Law (Federal Law n. 12.527/2011) (Lei n. 15.527, 2011), is also of great importance. By opening data on immigration to Brazil to a greater public, the government will encourage more studies on the matter and new ways to qualify the debate on this issue, which can help subsidize public policy.

These policy suggestions are currently especially valid, considering recent legislative moves regarding migration. Federal law n. 13.445/2017 creates a window of opportunity for change regarding the Brazilian immigration administration and policy. However, little has been said on how the law will be regulated as it entered into force on November 21, 2017. So, there is still much to be discussed and done in order for Brazil to update its processes to international standards, regarding both benefiting from windows of opportunity to attract talents - and use them as a factor for development - and respecting the rights of refugees - and committing to its international responsibilities.

The integration and harmonization of processes would generate more cooperation and integration among the bodies responsible for the immigration policy and administration. By doing so, people and companies will no longer communicate with different bodies, but with the Brazilian State. This would generate more qualified statistics and promote actions to insert the immigrant in the labor market more effectively and to integrate the refugee on more human bases. This would not only contribute to the country's development, but also to the tasks performed by the involved ministries and governmental bodies.

\section{ReferenCes}

ABNT (2005). NBR ISO 9000:2005. Recuperado de https://qualidadeuniso.files.wordpress.com/2012/09/nbr-iso9000-2005.pdf

Cury, A. (2005). Organização e métodos: uma visão holística, Atlas, São Paulo. 
Cruz, Tadeu (2010). Sistemas, métodos \& processos: administrando organizações por meio de processos de negócios. Atlas, São Paulo.

Department of Immigration and Border Control - Statistics. (2017). Canberra. Recuperado de https://www.border.g ov.au/about/reports-publications/research-statistics/statistics

Destatis - Migration \& integration. (2017). Berlin. Recuperado de https://www.destatis.de/EN/FactsFigures/Societ yState/Population/MigrationIntegration/MigrationIntegration.html

Ferreira, André Ribeiro. (2013). Gestão de processos. módulo 3. ENAP/DDG, Brasília.

Fundação Getulio Vargas/Department of Public Policy Analysis. (2015). Análise e Avaliação do Desenvolvimento Institucional da Política de Imigração para o Século XXI, FGV/DAPP, Rio de Janeiro. Recuperado de http://da pp.fgv.br/wp-content/uploads/2016/05/Imigracao_Online.pdf

Fundação Getulio Vargas/Department of Public Policy Analysis. (2017). Refúgio no Brasil: Avanços Legais e Entraves Burocráticos, FGV/DAPP, Rio de Janeiro. Recuperado de http://dapp.fgv.br/refugio-no-brasil-avancos-legais-e -entraves-burocraticos/

Gonçalves, José Ernesto Lima (2000). As Empresas São Grandes Coleções de Processos. RAE - Revista de Administração de Empresas, 40(1), 6-19.

IBGE - Instituto Brasileiro de Geografia e Estatística (2017), Resultado da Amostra do Censo, Rio de Janeiro. Recuperado de http://www.ibge.gov.br/home/estatistica/populacao/censo2010/default_resultados_amostra.s htm

IRCC - Statistics and Open Data. (2017). Ottawa. Recuperado de http://www.cic.gc.ca/english/resources/statistics /index.asp

Lista de Membros do Conselho Nacional de Imigração. (2017). MTE, Brasília. Recuperado de http://trabalho.gov.br/i mages/Documentos/Trabalhoestrangeiro/LISTA-DE-MEMBROS-CNIg-2016-SITE.pdf

Lei n. 6.815, de 19 de agosto de 1980. (1980). Presidência da República, Brasília. Recuperado de http://www.planalt o.gov.br/ccivil_03/leis/L6815.htm

Lei n. 13.445, de 24 de maio de 2017. (2017). Presidência da República, Brasília. Recuperado de http://www.planalt o.gov.br/ccivil_03/_ato2015-2018/2017/lei/L13445.htm

Lei n. 15.527, de 18 de novembro de 2011. (2011). Presidência da República, Brasília. Recuperado de http://www.pla nalto.gov.br/ccivil_03/_ato2011-2014/2011/lei/112527.htm

OBMigra - Observatório das Migrações Internacionais (2017), Sincre, Brasília. Recuperado de http://obmigra.mte.g ov.br/index.php/component/k2/itemlist/category/51\%20Inbox\%20x

OECD (2016), International Migration Outlook 2016, OECD Publishing, Paris. Recuperado de http://dx.doi.org/1 0.1787/migr_outlook-2016-en

Oliveira, Antônio Tadeu Ribeiro de (2016). Relacionamento e Complementariedade entre as Fontes de Dados sobre Migrações Internacionais: um estudo exploratório revisado. In: Cavalcanti, Leonardo, Antônio Tadeu Ribeiro de Oliveira, and Dina Araujo (Orgs.), Relatório Anual 2016: A inserção dos imigrantes no mercado de trabalho Brazileiro, OBMigra, Brasília.

Refúgio em Números. (2016). Brasília: Ministry of Justice. Recuperado de http://www.justica.gov.br/noticias/Braziltem-aumento-de-12-no-numero-de-refugiados-em-2016/20062017_refugio-em-numeros-2010-2016.pdf

Resolução Normativa n. 102, de 12 de janeiro de 2012. (2012). Conselho Nacional de Imigração, Brasília. Recuperado dehttps://www.legisweb.com.br/legislacao/?id=116083

Singleton, Ann (2016). Global Migration Group Migration and Development Data Handbook. KNOMAD, Washington.

UNHCR - United Nations Human Rights Council (2017). UNHCR Statistics, Geneva. Recuperado de http://pop stats.unhcr.org/en/overview\#_ga=2.68032727.717824037.1498150865-255199763.1498150865

Wesker, Mathias (2012). Business Process Management: Concepts, Languages, Architectures. Springer, New York. 


\section{NoTES}

[i]ICOM: I - Input, C - Control, O - Output, M - Mechanism.

[ii] The former law on migration in Brazil dates back to 1980, the so called "Statute of Foreigner", and can be found in Brazil (1980), while the new Migration Law was approved can be found in Law n. 13.445, May $24^{\text {th }}, 2017$.

[iii]Today, social security issues are treated within the Ministry of Finance, under the Social Security Secretariat.

\section{BY-NC-ND}

